\title{
Literackie obrachunki z dzieciństwem na zesłaniu w Związku Sowieckim Wstępne rozpoznanie
}

Wśród literackich utworów poświęconych tematyce drugiej wojny światowej na uwagę zasługują teksty autorów, którzy dzieciństwo przeżyli na zesłaniu w Związku Sowieckim i niejednokrotnie dopiero po kilkudziesięciu latach, „zdejmując pieczęć z pamięci”', powrócili do tych doświadczeń w swojej twórczości. Sposób ujęcia i literackiego przetworzenia tematyki deportacji i zsyłek do ZSRR różni je od narracji pisarzy, którzy wojnę przeżywali jako dorośli. Odmienność dziecięcej perspektywy w prozie dostrzegła Izabella Sariusz-Skąpska. Jednak w monografii Polscy świadkowie GUŁagu. Literatura lagrowa 1939-1989² badaczka omówiła tylko utwory publikowane do końca lat osiemdziesiątych, a w wolnej Polsce zaczęły ukazywać się kolejne teksty podejmujące ten temat. Rozpoczęte badania domagają się więc kontynuacji.

Do schyłku lat osiemdziesiątych tematyka dzieciństwa przeżytego na zesłaniu w Związku Sowieckim była w naszym kraju praktycznie nieobecna ze względu na sytuację polityczną. Wcześniej podjęli ją, w zakresie, na jaki wówczas pozwalała cenzura i autocenzura, Zbigniew Domino (urodzony w 1929 r.) w tomie opowiadań Cedrowe orzechy (1974) oraz Jerzy Krzysztoń (urodzony w 1931 r.) w powieści Wielbłąd na stepie (1978), prozaicy dostrzeżeni przez autorkę wspomnianej monografii, podobnie jak Danuta Irena Bieńkowska. Utwory

* Dr hab., adiunkt; Uniwersytet Rzeszowski, Instytut Filologii Polskiej, Zakład Literatury Polskiej XX wieku; ul. Rejtana 16c, 35-959 Rzeszów; anwall@o2.pl.

${ }^{1}$ Sformułowanie pochodzi z motta poprzedzającego powieść Jerzego Krzysztonia Wielbłąd na stepie: „Cokolwiek przeżyłeś w dobrym czy złym zdejmij pieczęć z pamięci” (napis na kamieniu), J. Krzysztoń, Wielbłąd na stepie. Krzyż Poludnia, Czytelnik, Warszawa 1987.

2 I. Sariusz-Skąpska, Polscy świadkowie GUŁagu. Literatura łagrowa 1939-1989, Universitas, Kraków 2002, s. 180-182. 
tej emigracyjnej pisarki (urodzonej w 1927 r.), w których poruszyła temat deportacji i pobytu na zesłaniu w ZSRR, również ukazały się u schyłku lat siedemdziesiątych, a ściślej w 1978 roku w zbiorowym tomie jej dzieł Między brzegami. Poezja i proza ${ }^{3}$ już po śmierci tragicznie zmarłej pisarki.

Natomiast dziesięć lat później, czyli prawie pół wieku po zakończeniu II wojny światowej, w wolnej Polsce, pojawiła się nowa fala powieści. Ich autorami byli przedstawiciele ostatniej generacji pamiętającej wojnę i mający za sobą doświadczenia zesłania w głąb Związku Sowieckiego, które uczynili tematem literackiej twórczości. Utwory te przynależą zarazem do trzeciej fazy rozwoju literatury łagrowej, którą, jak pisał Eugeniusz Czaplejewicz, cechuje przede wszystkim to, że zaczyna ukazywać się w kraju oraz że zwraca uwagę jej „,nowy ton i nowy styl”"4. Wydano wówczas także wiele tomów wspomnień zesłańców i więźniów łagrów, ale pozostają one poza obszarem moich zainteresowań.

Do wojennych przeżyć z okresu dzieciństwa i młodości w ZSRR powrócili m.in. Andrzej Turczyński w opowiadaniu Chłopiec na czerwonym koniu (1991), Piotr Bednarski w utworze Btękitne śniegi (1996), Andrzej Czcibor-Piotrowski w powieści Rzeczy nienasycone (1999) oraz Zbigniew Domino kontynuujący w Syberiadzie polskiej (2001) temat rozpoczęty w latach siedemdziesiątych. Kilka lat później pisarz ten rozwinął pominięte wcześniej syberyjskie wątki i wydał dwuczęściową książkę Tajga. Tamtego lata w Kajenie (2007). Znamienne, że pozostali prozaicy również nie poprzestali na jednym utworze opisującym pobyt na zesłaniu, ale kontynuowali je, tworząc cykle powieściowe o dalszych wojennych i powojennych losach dzieci, które przeżyły pobyt na zesłaniu w ZSRR ${ }^{5}$.

Ryszard Kapuściński, pisarz urodzony w 1932 roku, we wstępie do Fragmentów niespokojnego dzieciństwa Adama Czerniawskiego, tak uzasadniał powrót literatów w latach dziewięćdziesiątych do tematyki wojennej:

II wojna światowa - w miarach kalendarzowych - trwała pięć lat. Ale dla tych, którzy ją przeżyli, w jakimś sensie toczy się ona nadal, czasem już zepchnięta na margines i w zakamarki naszej pamięci, ale jednak nigdy ostatecznie i bez śladu nie wy-

${ }^{3}$ O twórczości Danuty Ireny Bieńkowskiej, także o tematyce zesłańczej w jej prozie pisała Agata Paliwoda. Zob. taż, ,, Swoja i obca”. Twórczość literacka Danuty Ireny Bieńkowskiej, Wydawnictwo Uniwersytetu Rzeszowskiego, Rzeszów 2015.

${ }^{4}$ E. Czaplejewicz, Polska literatura lagrowa, Wydawnictwo Naukowe PWN, Warszawa 1992, s. $49-52$.

${ }^{5}$ Jerzy Krzysztoń wydał Krzyż Południa, Zbigniew Domino Czas kukułczych gniazd, Młode ciemności, Tajga. Tamtego lata w Kajenie, Andrzej Czcibor-Piotrowski Cud w Esfahanie i Strasz$n e d n i$, a Andrzej Turczyński Tryptyk Ruski, na który złożyły się utwory Upadek w Tartarię, Chtopiec na czerwonym koniu, Spalone ogrody rozkoszy, Piotr Bednarski Btękitne śniegi i inne rejsy po złote runo (całość tworzą: Błękitne śniegi, Rejsy po arcydzieło, Śnieżne kraby). Wskazane w tym artykule cykle pozostają poza kręgiem moich zainteresowań, niemniej interpretacja utworów z uwzględnieniem porządku, który zaproponowali autorzy, stworzyłaby nowe konteksty. 
mazana. Wracamy do niej, staramy się odtworzyć jej obrazy, wypełnić coraz większe - w miarę upływu lat - luki, odnaleźć tamte dni i miesiące, odrodzić ich barwę, ich zapach i natężenie ${ }^{6}$.

Również Andrzej Turczyński w autotematycznych dygresjach opowiadania Chłopiec na czerwonym koniu podkreśla, jak trudna jest egzystencja z ciągle „,̇ywą pamięcią" traumatycznych wydarzeń wojennego dzieciństwa. Ważna zatem, zdaniem pisarza, stała się potrzeba ich opowiedzenia.

Autorzy prozy zsyłkowo-łagrowej, należący do pokolenia ,tułaczych dzieci”, stanęli przed problemem odzyskiwania wspomnień z dzieciństwa, zmagania się z pamięcią, czemu dali wyraz w metatekstowych komentarzach. Na przykład narrator-bohater opowiadania Chłopiec na czerwonym koniu, mając świadomość, że upływ czasu utrudnia porządkowanie oraz odzyskiwanie obrazów z dzieciństwa, wyznaje: „Nie wystarczy [...] powiedzieć sobie: teraz będę wspominał, - bo nic to nie znaczy ani prowadzi do wspomnień. Wspomnieć coś to znaczy ujrzeć przed «oczyma duszy». Ta zasię nie pojawia się na zawołanie"7. W innym miejscu tak opisuje kłopoty z pamięcią autobiograficzną, którą rządzą charakterystyczne dla niej mechanizmy, przez psychologów określane amnezją dziecięcą

Pomieszało mi się wszystko. Pokłębiło. Zwęźliło. Zasupłało w czasie tym, co po tamtym czasie. Dzisiaj jako początek tajemnicy jutra, a to znów jako ogień przeniesiony z wczorajszego wieczora. Żeby tak na pewno, naprawdę, ale jak? Jeśli nie z ułamków, obłamków - to jak? ${ }^{9}$

Nie bez znaczenia dla sposobu przedstawiania wojennego dzieciństwa było to, ile lat mieli przyszli prozaicy w momencie zsyłki. Większość autorów interpretowanych utworów należy do pokolenia określanego jako „dzieci wojny”, a więc tych, którzy urodzili się przed rozpoczęciem II wojny światowej, dzięki czemu, jak zauważa Sławomir Mrożek, nie tylko ją pamiętali, ale podczas jej trwania mogli wiedzieć, że jest alternatywą pokoju ${ }^{10}$. Natomiast urodzeni nieco później Andrzej Turczyński (ur. w 1938 r.) oraz Piotr Bednarski (ur. 1938 r.), jak i bohaterowie ich powieści, tej pamięci czasu pokoju nie posiadali, co autor Błękitnych śniegów niejednokrotnie podkreśla:

\footnotetext{
${ }^{6}$ R. Kapuściński, wstęp do: A. Czerniawski, Fragmenty niespokojnego dzieciństwa, Aneks, Londyn 1995, s. III.

${ }^{7}$ A. Turczyński, Chłopiec na czerwonym koniu, w: tenże, Tryptyk ruski, Orthdruk, Białystok 1998, s. 121.

${ }^{8}$ Por. M. Jagodzińska, Rozwój pamięci w dzieciństwie, Gdańskie Wydawnictwo Psychologiczne, Gdańsk 2003, s. 131-160.

${ }^{9}$ A. Turczyński, dz. cyt., s. 90.

${ }^{10}$ Por. S. Mrożek, Małe listy, Wydawnictwo Literackie, Kraków 1982, s. 142.
} 
Na ogół nie dostrzegaliśmy naszej nędzy oraz panoszącej się śmierci - konstatuje narrator-bohater Btękitnych śniegów. - Był to nasz świat, nasza rzeczywistość, nasza codzienność. Niczego innego nie znaliśmy, albo zapomnieliśmy. [...]

Rzeczywistość była okrutna, gorsza niż jaskiniowców, lecz nam było dobrze, bo nie znaliśmy dobra. Mało kto mówił o przeszłości. A jeśli któryś z europejskich dziadków rozklejał się i zaczynał opowieść o cywilizowanym kraju, słuchaliśmy go niczym bajki ${ }^{11}$.

Większość pisarzy, z wyjątkiem Dominy ${ }^{12}$, zaakcentowała autobiograficzny charakter swojej prozy, wpisując siebie z imienia, a niekiedy i nazwiska w obręb świata przedstawionego. Piotr Bednarski zawarł ,pakt autobiograficzny” z czytelnikiem dopiero na ostatniej stronie swojej książki, w scenie, w której przybrana matka przejmuje nad bohaterem opiekę, oświadczając: „Pamiętaj, jestem teraz twoją matką i nazywasz się Bednarski. A imię masz identyczne jak mój syn. Strzeżonego Pan Bóg strzeże"13.

Prozaicy „pokolenia wojennego”, podejmujący tematykę deportacji i zsyłek w głąb ZSRR sięgali po odmienne strategie przedstawiania wojennej rzeczywistości - od realistycznych po metaforyzujące i mitologizujące. W ich utworach, między innymi za sprawą dużego dystansu czasowego, ważna stała się nie tylko faktografia, ale także walory czysto literackie. Krytycy zwracali uwagę na to, że omawiani pisarze jako formę „obrachunków z wojennym dzieciństwem” (określenie Zbigniewa Dominy) ${ }^{14}$ wybierali nie dokumentalno-reportażowe wspomnienia, lecz podejmowali - co podkreśla Magdalena Rabizo-Birek - „«literackie» $\mathrm{i}$ «fikcjonalne» zadania ewokowania i odtwarzania świata dziecięcych doznań"15. Prozaicy zapisywali wspomnienia z zesłania w różnorodny sposób, na ogół swobodnie nimi rozporządzając. Akcentowali nie tylko autobiograficzne korzenie swojej prozy, ale także jej autonomiczny i wyobraźniowy cha-

${ }^{11}$ P. Bednarski, Btękitne śniegi, Volumen, Warszawa 1996, s. 5.

${ }^{12}$ W Syberiadzie polskiej oraz dwuczęściowym utworze Tajga. Tamtego lata w Kajenie Domino wyposażył członków rodziny Dolinów w biografię swoją i swoich najbliższych (rodziców i młodszego brata). W wielowątkowej powieści zajmuje ona uprzywilejowane miejsce. Natomiast w Cedrowych orzechach narratora- bohatera Staszka Dolinę można uznać za porte parole autora. Wykorzystując biografię swojej rodziny, pisarz swobodnie ją przetwarza, modyfikuje. Zmienia nazwiska bohaterów, nazwy miejscowości (rodzinna Kielnarowa w utworach prozatorskich funkcjonuje jako Kalinowa), posługuje się różnymi wersjami wydarzeń. Na przykład w tytułowym opowiadaniu z tomu Cedrowe orzechy Staś Dolina otrzymuje informację o śmierci ojca na froncie, w późniejszej dylogii w tomie Czas kukutczych gniazd syn i ojciec odnajdują się na Ziemiach Odzyskanych.

${ }^{13}$ P. Bednarski, dz. cyt., s. 123.

${ }^{14}$ Kukutcze gniazda po Syberiadzie, ze Z. Domino rozm. H. Kowalik, „Przegląd” 2004, nr 44, s. 37.

${ }_{15}$ M. Rabizo-Birek, Syberyjski apokryf, czyli apostoł Piotr i jego drużyna, „Twórczość” 1997, nr 7, s. 107. 
rakter oraz korzystanie z prawa do artystycznych transformacji i transgresji ${ }^{16}$. Te ostatnie obserwujemy w utworach Turczyńskiego, Czcibora-Piotrowskiego i Bednarskiego.

Anna Jamrozek-Sowa, podkreślając ,wybitnie fabularny charakter” tekstów wspomnianych prozaików, tak je charakteryzuje:

Ich autorzy uciekają się do metaforyzacji realności, odwołują się do bliskiej dziecięcej wyobraźni poetyki baśni, przypowieści. Młodzi bohaterowie na krzywdy doznane od radzieckiego państwa reagują tworzeniem autonomicznego, onirycznego świata, w którym realizują się ich marzenia o ocaleniu swojego życia i ich najbliższych, o triumfie piękna i dobra nad złymi mocami ucieleśnianymi przez komunistycznych funkcjonariuszy ${ }^{17}$.

Sposób pisania o doświadczeniach zsyłkowo-łagrowych, odbiegający od stosowanych dotychczas konwencji podejmowania tej problematyki, był zaskoczeniem, co potwierdza recepcja opowiadania Turczyńskiego Chłopiec na czerwonym koniu. Mieczysław Orski, zwracając uwagę na to, że u pisarza „trudno wymierzyć przedział między faktami i zmyśleniami”, tak komentował sposób opisu sowieckiej rzeczywistości w utworze:

Nawet jeśli [Turczyński] odwołuje się do jakichś autentycznych źródeł, dokumentów pamięci (choć trudno uwierzyć w koincydencję aż tylu potworności bytu, w jakie narrator wplątuje gromadkę dzieciaków mrących jeden po drugim, a także przewożonych w innych wagonach tegoż transportu kobiet), to na zasadzie spiętrzenia ich, skontaminowania w oryginalną artystyczną syntezę - czy też metaforę będącą kwintesencją doniesień rzeczywistości skrzywdzonych i poniżonych ${ }^{18}$.

Turczyński przedstawił w opowiadaniu, rzadki w polskiej literaturze, obraz łagru dla dzieci. Obóz nosił znaczącą nazwę „Gułartek”" nieletni więźniowie pracowali w nim w skrajnie trudnych warunkach przy wydobyciu torfu. Prozaik połączył w utworze brutalizm i okrucieństwo realistycznego konkretu, za pomocą którego ukazał sposoby represjonowania tak dzieci, jak i dorosłych, z elementami baśni, legendy, fantastyki. W opowieści o wojennych losach głównego bohatera

\footnotetext{
${ }^{16}$ Por. H. Bereza, Zamiast wstęu..., w: Sylwetki pisarzy stupskich. Andrzej Turczyński. Bio-bibliografia, oprac. A. Świetlicka, Stowarzyszenie Bibliotekarzy Polskich, Miejska Biblioteka Publiczna im. Marii Dąbrowskiej, Słupsk 2003, s. 10.

${ }^{17}$ A. Jamrozek-Sowa, Wojna raz jeszcze. Obrazy II wojny światowej w prozie lat dziewięćdziesiatych, w: Literatura polska 1990-2000, red. T. Cieślak, K. Pietrych, Zielona Sowa, Kraków 2002, t. 2, s. 101.

${ }^{18}$ M. Orski, Chłopiec z gułagu, „Przegląd Powszechny” 1992, nr 11, s. 341.

${ }^{19}$ Nazwa odsyła centralnego obozu pionierskiego na Krymie - Artek, który został założony w 1925 r. W utworze, w tym nawiązaniu pobrzmiewa gorzka ironia.
} 
zastosował stylizację na baśń oraz wykorzystał rosyjską legendę o ptaku Sirinie i Ałkonoście. W stylizacji baśniowej pisarz posłużył się znanym motywem popularnej piosenki szlacheckiej Ty pójdziesz górą, która stała się komentarzem do losów głównego bohatera utworu, tytułowego Chłopca pochodzącego z rodziny ziemiańskiej oraz opiekującej się nim po śmierci matki i siostry wiejskiej dziewczyny Anastazji. Dopełnieniem jest oniryczno-baśniowe zakończenie opowiadania i jego metaforyczne znaczenie ${ }^{20}$. Do tego wątku powrócę w dalszych rozważaniach.

„Mityzacji rzeczywistości” dokonali także Bednarski w utworze Błękitne śniegi, nadając mu formę przypowieści, oraz Czcibor-Piotrowski. W jego powieści Rzeczy nienasycone nie jest najważniejsza rekonstrukcja faktów, czyli przedstawienie życia zesłańców w Paninie, lecz świat intymnych doznań kilkuletniego chłopca. Podkreślił to Grzegorz Leszczyński: „Podróż w przeszłość prowadzi do poszukiwania prawdy o sobie, nie o zdarzeniach, te o tyle tylko mają sens o ile fundują tożsamość człowieka, jego jestestwo, byt, kondycję ludzkąa"21. Obecność wątku tożsamościowego istotna jest także w prozie wspomnieniowej Turczyńskiego, który w opowiadaniu Chtopiec na czerwonym koniu kreuje narratora-bohatera poszukującego odpowiedzi na pytanie, kim jest on sam, czyli Chłopiec, którym był w dzieciństwie:

Jestem tamtym i: nie jestem, bo już kimś innym jestem, choć: chłopiec, chłopca, chłopcu, chłopca, nigdy inaczej tylko: Chłopiec. Aż po zwątpienie: jak to, tamten to ja? Co było, odnajduję w swej jestności, teraźniejszości okamgniennej?22

Domino natomiast powrót do wojennego dzieciństwa nazwał próbą ,zrozumienia swojego czasu"23.

Odwołując się do ustaleń narratologii, a ściślej narracyjnej koncepcji tożsamości jednostki ludzkiej, możemy powiedzieć, że powrót do traumatycznych wydarzeń z dzieciństwa w prozie wspomnieniowej pisarzy urodzonych w latach 30 . dał im szansę na uporządkowanie przeszłości, a walka o dostęp do siebie sprzed lat i próba zrozumienia siebie samego miała wymiar terapeutyczny, służyła reintegracji podmiotu oraz nadaniu sensu egzystencji ${ }^{24}$.

\footnotetext{
${ }^{20}$ Mieczysław Orski, recenzując tom, pisał o zakończeniu bardzo krytycznie: „Nie wydaje mi się, żeby do tego stopnia zwykły kryminał historyczny można było mieszać z lirycznie natchnioną baśnią". M. Orski, dz. cyt., s. 342.

${ }^{21}$ G. Leszczyński, Gra w dzieciństwo. Proza wspomnieniowa schyłku wieku, w: Pisać poza rok 2000. Studia i szkice literackie, red. A. Lam, T. Wroczyński, Elipsa, Warszawa 2002, s. 227.

${ }^{22}$ A. Turczyński, dz. cyt., s. 90.

${ }^{23}$ W wywiadzie pisarz stwierdził: „Nie jestem historykiem. Nie wymierzam sprawiedliwości doznanemu światu. Chciałem tylko zrozumieć swój czas". Do zobaczenia w filmie, ze Z. Dominą rozm. H. Kowalik, „Przegląd” 2007, nr 27, s. 46.

${ }^{24}$ Por. K. Rosner, Narracja, tożsamość i czas, Universitas, Kraków 2003, s. 33.
} 
W interpretowanej prozie obecny jest także imperatyw dawania świadectwa, choć nie tak wyraźnie formułowany jak w powstającej tuż po zakończeniu wojny lub nieco później literaturze zsyłkowo-łagrowej. W opowiadaniu Chłopiec na czerwonym koniu pisarz przedstawił ten motyw, kreując oniryczną scenę, w której bohater odbył wyprawę do legendarnego ptaka Sirina i wówczas: „zostanie Chłopiec [...] naznaczony poczuciem obowiązku jak blizną, - relacjonuje narrator - obowiązkiem świadczenia, śpiewania i opowiadania"25. Tytułowa postać utworu Turczyńskiego misję świadczenia podejmie jako formę ocalenia pamięci o tych, których kochał i w Związku Sowieckim utracił.

Kontynuując refleksję nad wyborem strategii pisarskich, służących przedstawianiu wojennej przeszłości, należy podkreślić, że Domino oraz Krzysztoń pozostali wierni konwencji realistycznej. Krzysztoń na okładce swojego utworu pisał: „Choć nie jest to pamiętnik, tylko powieść, Wielbłąd na stepie nie powstał z wyobraźni, lecz z młodzieńczego doświadczenia”" ${ }^{26}$. Z kolei Domino w adnotacji poprzedzającej Syberiade polska informował: „Wszystko, o czym w tej książce opowiemy, wydarzyło się naprawdę albo wydarzyć się mogło"27.

Krzysztoń i Domino (w swoim drugim utworze o tematyce syberyjskiej, pierwszym był tom opowiadań Cedrowe orzechy), stosując realistyczny sposób przedstawiania wojennych doświadczeń i narrację trzecioosobową, dążyli do obiektywizacji, czyli nie tylko do oddania indywidualnych, niepowtarzalnych losów swoich i rodzin, ale także większych grup lub społeczności. W utworze Krzysztonia Wielbłą na stepie opowieść obejmuje dzieje bliskich sobie kobiet z Grodna i ich rodzin zesłanych do Kazachstanu. Przy czym autor powieści rozpoczyna narrację o losach mieszkańców Grodna deportowanych do kołchozu Obuchowka dopiero od chwili, gdy w 1941 r. odzyskają wolność wskutek amnestii, która objęła Polaków po układzie Majski-Sikorski. Wówczas, mimo że zyskali swobodę przemieszczania się, nie skończyła się ich tułaczka po ZSRR i walka o przetrwanie, musieli bowiem nadal ciężko pracować, by żyć na terenie komunistycznej Rosji, w skrajnie trudnych warunkach bytowych, aż do momentu, kiedy zostaną ewakuowani wraz z Armią Andersa.

Natomiast Syberiada polska Dominy odtwarza historię większej gromady - wiejskiej wspólnoty podolskiej wioski Czerwony Jar, a wśród nich rodziny Dolinów. Wszyscy jako tzw. specpieriesieleńcy nakazem NKWD zostali skazani na przesiedlenie na tereny Syberii, do Kaluczego nad rzeką Pojmą, gdzie istniał przymus pracy oraz obowiązywał rygor łagrowy. Domino, opisując wojenne losy społeczności składającej się z mieszkańców podolskiej wsi i jej okolic, wprowadził w przestrzeń wojennych obrachunków dosyć rzadko podejmowany temat chłopskiej

\footnotetext{
${ }^{25}$ A. Turczyński, dz. cyt., s. 156.

${ }^{26}$ J. Krzysztoń, Wielbład na stepie, Czytelnik, Warszawa 1978.

${ }^{27}$ Z. Domino, Syberiada polska, Studio Emka, Warszawa 2001.
} 
martyrologii, dotychczasowe bowiem świadectwa wojennych okrucieństw wiązały się raczej z doświadczeniami inteligenckimi bądź dotyczyły ludności miast ${ }^{28}$.

Obydwaj prozaicy, Krzysztoń i Domino, konstrukcję utworów oparli na porządku chronologicznym, który najczęściej służył realistycznemu przedstawieniu losu Polaków na ziemiach okupowanych przez ZSRR. Zbigniew Domino w powieści Syberiada polska starał się przedstawić wszystkie etapy deportacji mieszkańców podolskiej wsi, począwszy od załadunku do pociągu, poprzez bardzo długą podróż na Syberię, odbywaną różnymi środkami komunikacji. Opisał również warunki bytowe na zesłaniu oraz pracę dorosłych i dzieci powyżej 14 roku życia. Siła tej prozy tkwi w dokładności, rzeczowości opisu, który służy nie tylko utrwaleniu przebytych etapów na terenie Syberii, ale także odtworzeniu warunków codziennej egzystencji w poszczególnych miejscach pobytu aż do momentu, gdy ci mieszkańcy wsi Czerwony Jar, którzy zdołali przeżyć, opuścili tereny ZSRR w 1946 r. w specjalnym pociągu repatriacyjnym.

Historia zesłańców przedstawiona w utworze ma wiele miejsc wspólnych z innymi tekstami literatury łagrowej. Można powiedzieć, że bliska jest syntetycznej i modelowej strukturze dzieła zsyłkowo-łagrowego, mieszczącego schemat polskiego losu, wydobywającego jego martyrologiczny aspekt $\mathrm{t}^{29}$. Do stałych toposów ukształtowanych jeszcze w romantyzmie należy motyw Sybiru. Domino, zgodnie z obowiązującym w polskiej tradycji zwyczajem, używa powyższej nazwy, która nie odnosi się tylko i wyłącznie do Syberii jako obszaru geograficznego, ale funkcjonuje również jako pojęcie polityczne związane $\mathrm{z}$ „wygnańczym doświadczeniem narodowym" 30. Chcąc głębiej osadzić doświadczenie Sybiru w historii i kulturze polskiej, prozaik przywołuje motyw pielgrzymowania, tułactwa, popularny w literaturze romantyzmu za pośrednictwem utworów Adama Mickiewicza (cytuje m.in. Modlitwe pielgrzyma zaczerpniętą z Ksiag narodu polskiego i pielgrzymstwa polskiego). Pisarz dostrzega paralele losów dziewiętnastoi dwudziestowiecznych zesłańców. Powieść Dominy zwracała uwagę swym epickim rozmachem, wielowątkowością, określano ją mianem eposu o losie polskich zesłańców ${ }^{31}$. Krytycy docenili walory literackie ${ }^{32}$ Syberiady polskiej, a w 2013 roku Janusz Zaorski na jej podstawie zrealizował film fabularny ${ }^{33}$.

\footnotetext{
${ }^{28}$ Por. Z. Brzuchowska, Epos nadziei, „Fraza” 2004, nr 3-4, s. 305.

${ }^{29}$ Por. T. Bujnicki, Obrazy ,innego świata” (Losy Polaków w latach 1939-1945 na terytorium ZSRR w emigracyjnej prozie literackiej), „Przegląd Humanistyczny” 1990, nr 4, s. 33, 36-39; I. Sariusz-Skąpska, dz. cyt., s. 67 i n.

${ }^{30}$ Por. A. Kubajak, Sybir i Syberia w dziejach narodu polskiego, Kubajak, Krzeszowice 2008, s. 5.

${ }^{31}$ Termin epos pojawia się w tytułach recenzji: np. A. Niewolak, Epos o polskim losie?, „Fraza” 2001, nr 4; Z. Brzuchowska, Epos nadziei.

32 Por. T. Lewandowski, Dymiąca rana Syberii, „Nowe Książki” 2001, nr 8, s. 34-35; W. Nawrocki, Sybir poza legenda, „Dziś” 2003, nr 2, s. 121.

${ }^{33}$ Natomiast autor książki, a ściślej jego biografia, są przyczyną licznych kontrowersji. W 1948 roku Domino wstąpił do Korpusu Bezpieczeństwa Wewnętrznego, później pracował
} 
W pozostałych spośród omawianych utworów, czyli w opowiadaniach powiązanych osobą narratora-bohatera z tomów Cedrowe orzechy Dominy, Błękitnych śniegach Bednarskiego, w opowiadaniu Chtopiec na czerwonym koniu Turczyńskiego oraz powieści Rzeczy nienasycone Czcibora-Piotrowskiego, ich autorzy prezentują wizję II wojny światowej uprywatnioną, postrzeganą z perspektywy pojedynczego człowieka, przemocą wciągniętego w tryby niszczącej historii, a w dodatku dziecka lub młodzieńca. Prozaicy stosują narrację pierwszoosobową. Tym samym opowieść zostaje zawężona do losów narratorów-bohaterów, ich rodzin i najbliższych. Warto tutaj dodać, że świadomość narratorów-bohaterów na ogół znacznie wykracza poza horyzont kilkuletnich bądź nastoletnich chłopców, tak w zakresie rozumienia spraw dotyczących dorosłych oraz doświadczeń, słownictwa, znajomości skomplikowanej sytuacji w świecie. Ja-wspominający i ja-wspominany to dwie odrębne osoby ${ }^{34}$. Narrator-bohater Btękitnych śniegów kilkakrotnie komentuje taki stan rzeczy: „Nie wiedziałem wtedy jeszcze o tym”, 35 , zaznaczając inny stan wiedzy od tego, który posiadał jako dziecko. Natomiast narrator w opowiadaniu Turczyńskiego siebie sprzed lat nazywa Chłopcem, podkreślając dystans między dojrzałym człowiekiem i jego odległym pierwowzorem - dzieckiem z czasu wojny. W autotematycznym komentarzu stwierdza:

Skoro bowiem podjąłem się opowiedzieć historię tamtego Chłopca i jednocześnie zdać sprawę z mojego dzisiaj punktu widzenia, muszę nieustannie pytać o istotę czasu, jego sens i treści, które tyleż on rodzi, ile i one tworzą jego ${ }^{36}$.

W interpretowanych utworach uwarunkowane przez historię „tułacze” i „zniewolone dzieciństwo”, pełne głodu, cierpienia, lęku, doświadczeń progowych zostaje odtworzone i zrekonstruowane z perspektywy wiedzy i wrażliwości człowieka dorosłego. Powrót do dzieciństwa staje się sposobem na rozliczenie z własną przeszłością i zarazem Historią, a przede wszystkim jest poszukiwaniem samego siebie. Ta perspektywa odróżnia omawiane utwory od ,artystycznych świadectw", których autorzy przebywali na zesłaniu jako dorośli. Proza „pokolenia wojennego" charakteryzuje się także odmienną topiką.

w Naczelnej Prokuraturze Wojskowej (w latach 1950-1973) i Głównym Zarządzie Politycznym LWP (1973-1975). Od 1949 roku był członkiem PZPR, por. Domino Zbigniew, w: Współcześni polscy pisarze i badacze literatury. Stownik biobibliograficzny, red. J. Czachowska, A. Szałagan, t. 2, Wydawnictwa Szkolne i Pedagogiczne, Warszawa 1994, s. 193.

${ }^{34}$ Por. G. Leszczyński, Dzieciństwo utracone. O prozie wspomnieniowej, w: tenże, Kulturowy obraz dziecka i dzieciństwa w literaturze drugiej połowy XIX $i$ wXX w. Wybrane problemy, Wydział Polonistyki Uniwersytetu Warszawskiego, Warszawa 2006, s. 338.

${ }^{35}$ P. Bednarski, dz. cyt., s. 7.

${ }^{36}$ A. Turczyński, dz. cyt., s. 121. 
Do powtarzających się motywów (toposów) w literaturze podejmującej temat wojennego dzieciństwa na zesłaniu w sowieckiej Rosji można zaliczyć m.in. obraz rodziców (głównie matki), motyw przyjaźni i rówieśniczych grup oraz motywy przygody i inicjacji.

Deportacje obywateli zamieszkujących wschodnie ziemie Drugiej Rzeczpospolitej, w dużej mierze obejmujące całe rodziny, sprawiły, że podstawowym punktem odniesienia w skrajnie trudnej sytuacji egzystencjalnej dzieci byli najbliżsi - rodzice, rodzeństwo, a przede wszystkim matki, centralne postaci świata dziecka. Eksponowana rola kobiet w prozie pokolenia ,tułaczych dzieci” wynikała także z sytuacji historycznej, z faktu, że samotnie walczyły one o przetrwanie rodzin na zesłaniu, podczas gdy mężowie, zmobilizowani we wrześniu 1939 roku, nie wrócili z wojska lub przebywali w więzieniach albo łagrach. Hołd matkom oddaje Krzysztoń w ostatnich scenach powieści Wielbłą na stepie słowami bohatera, jednego z żołnierzy Armii Andersa - Kaziuczka. Mężczyzna, obserwując byłych zesłańców, w dużej części kobiety i dzieci wsiadające na statek, który ma ich wywieźć w 1942 roku z sowieckiej Rosji, „Uświadomił sobie, że spogląda na nie z przymieszką dumy, uczuciem wdzięczności, że przedstawiały sobą, jakąś cząstkę odwagi przynależnej tradycją temu, co polskie. «Mój Boże, ileż ten naród zawdzięcza kobietom! - pomyślał - nie dosyć tego powtarzać do zachodu słońca»"37.

Motyw matki występuje w większości interpretowanych utworów ${ }^{38}$. Sposoby kreowania postaci kobiet różnią się w zależności od obranej przez poszczególnych pisarzy strategii przedstawiania wojennego dzieciństwa, od realistycznych po metaforyzujące i mitologizujące. W omawianej prozie wspomnieniowej odnajdujemy także różne typy macierzyństwa. Dominuje obraz matki z wytrwałością, zaradnością i wielkim wysiłkiem stawiającej opór nieludzkim warunkom życia na zesłaniu, walczącej o przetrwanie swoje i dzieci. Taką kreację stworzył na przykład w powieści Wielbłąd na stepie Krzysztoń. Matka dwóch bohaterów dziecięcych - Jerzego i Mariuszka - rozmyślając o nieobecnym mężu, od którego nie miała wiadomości od 1939 roku, i spoczywającej na niej odpowiedzialności za los dwóch synów, deklaruje: „A uchowa mu chłopców, choćby się waliło i paliło, bo już się zwaliło i spaliło, a jednak obaj żyli i rośli’’39.

W literackich kreacjach kobiet prozaicy eksponują nie tylko praktycyzm, zapobiegliwość, ofiarność w zmaganiu z wojenną codziennością, ale także podzi-

${ }^{37}$ J. Krzysztoń, Wielbłąd na stepie, w: tenże, Wielbłąd na stepie. Krzyż Poludnia, s. 225.

${ }^{38}$ Szeroko o nim pisała Agata Paliwoda, omawiając twórczość Bieńkowskiej. Por. taż, Doświadczenia zesłańcze, w: taż, „Swoja i obca”. Twórczość literacka Danuty Ireny Bieńkowskiej, s. $66-68$.

39 J. Krzysztoń, Wielbłąd na stepie, w: tenże, Wielbłąd na stepie. Krzyż Południa, s. 17. 
wianą, przez synów i otoczenie, urodę matek, ich młodość oraz mądrość. Matki to zarówno rodzicielki, żywicielki, ale też piękne i zmysłowe kobiety. Bohater powieści Krzysztonia Wielbłąd na stepie wyraża swój zachwyt wprost:

Jak to dobrze, że mam taką młodą matkę - pomyślał. - Lubię na nią patrzeć, bo jest świeżutka jak jabłuszko. I oczy ma takie swoje, na przekór pogodne, a kiedy je zmruży, ogrzać się można. [...] Czasem mam ochotę pocałować ją w usta, ale mi głupio i wstyd, bo jestem już duży chłopak ${ }^{40}$.

Analogicznie, czyli jako piękne kobiety, matki postrzegane są przez bohaterów Syberiady polskiej Dominy, powieści Rzeczy nienasycone Czcibora-Piotrowskiego, a także utworu Bednarskiego Błękitne śniegi. W ostatnim z nich matka bohatera, urzekająca mężczyzn niepowtarzalną, wręcz magiczną urodą, nosi metaforyczne imię Piękno. Jej uroda apoteozowana, wręcz mitologizowana przez narratora, zwraca także uwagę otoczenia i jest przyczyną wielu perypetii, a nawet śmierci zadawanych przez zazdrosnych o siebie adoratorów, wśród których są funkcjonariusze NKWD. Jest to więc portret femme fatale.

W kreacjach postaci matek pisarze eksponują to, że dla dzieci, w tym przypadku synów, były one nie tylko ideałem urody, ale także autorytetem i uosobieniem mądrości, wskazywały im bowiem świat wartości. Taką rolę pełni matka w życiu kilkuletniego Piotra - bohatera cyklu opowiadań Bednarskiego Btękitne śniegi. Kobieta ta - polska Żydówka - zgodnie z tradycją judaistyczną przemieszaną z religią katolicką, w oparciu o Biblię buduje świat wartości syna, opozycyjny wobec sowieckiej rzeczywistości zakłamanej i zniewalającej człowieka, uczy go rozróżniania dobra od zła. Dlatego utrata Biblii w transporcie do Rosji napawa ją przerażeniem. Bohater-narrator tak komentuje ten fakt:

Przez długie pierwsze tygodnie zesłania, przy każdej okazji, powtarzała, że bez Biblii czuje się tak, jakby ktoś jej ukradł tajemnicę serca. I mnie częściej niż zwykle całowała, przytulając do piersi. Drżała o mnie. A zaglądając w oczy szeptała: Jak ja ciebie bez Biblii wychowam. Ojciec - Bóg wie gdzie, Biblia spalona. Co ja pocznę. Przecież jeśli chłopiec od dzieciństwa nie czyta Pisma Świętego - przemienia się w diabła ${ }^{41}$.

Zdobyta przez matkę Piotra nowa Biblia (w języku rosyjskim) jest pilnie strzeżona i ukrywana. Staje się oparciem i podstawą moralnej edukacji bohatera, ale także źródłem nadziei, jego i grupy przyjaciół (,ferajny”), których zapoznaje z fragmentem Ewangelii według św. Mateusza mówiącym o Kazaniu na Górze. Religia jest zarazem sposobem przeciwstawienia się komunizmowi.

\footnotetext{
40 Tamże, s. 207.

${ }^{41}$ P. Bednarski, dz. cyt., s. 14-15.
} 
Również Krzysztoń w utworze Wielbłąd na stepie eksponuje rolę matki, która jest nie tylko piękna, ale przekazuje dziecku wiedzę o świecie i udziela wskazówek dotyczących postawy życiowej. Zbigniew Bitka zwraca uwagę na archetypowy aspekt obrazu matki (animy) „wtajemniczającej bohatera w misterium życia i śmierci” ${ }^{2}$. Jedna z ważniejszych scen powieści zawiera relację długiej rozmowy matki z synem, odbytej tuż przed wyjazdem ze Związku Sowieckiego, na dachu lepianki w Uzbekistanie. Matka udziela chłopcu rad, które odnoszą się do trudnych doświadczeń na zesłaniu, dotyczą postaw i wartości, jakimi syn powinien kierować się w życiu. Matka zachęca do akceptacji samego siebie, do otwarcia się na ludzi i świadczenia im dobra, co wyraża w następujących słowach:

Ale, widzisz, każdy ma swój los przeznaczony, zapisany od początku do końca. Sam go nie odczytasz zawczasu ani nie zmienisz. Nie odgadniesz, gdzie złożysz swoje kości [...], nie odgadniesz ani bólu, który cię czeka, ani strapienia, ani nieszczęścia. Gdybyś mógł to wszystko odgadnąć, bałbyś się żyć, a tak masz siłę przetrwać niejedno. [...] Tak, synku, polubić siebie na tyle, na ile się godzi i żyć śmiało, bez żadnej zawiści, bez obawy wyciągnąć ręce do drugich, pochylać się nad nieszczęściem i nie porzucić nikogo w potrzebie, garnąc się do innych, bo wtenczas oni się garną, to nie oni są przekleństwem, to samotność, i za skarby świata nie stracić humoru. Śmiać się z siebie do woli, bo to lepsze niż wszystkie pociechy. Równie dobre jak modlitwa. Jak sen. Uśmiechniesz się umierając, jeśliś wiedział jak żyćt3.

Wśród portretowanych matek są przedstawicielki różnych narodowości zamieszkujących wschodnie obszary Drugiej Rzeczpospolitej, nie tylko Polki, ale także Żydówki, Ukrainki pozostające w związkach z Polakami (te ostatnie to postacie dalszego planu). Ich portrety oddają w jakimś stopniu odrębności kulturowe w postrzeganiu roli rodziców w wychowaniu dzieci. Łączy je natomiast miłość do dzieci i bezgraniczne poświęcenie w walce o zapewnienie im przetrwania. Nie wszystkie portretowane kobiety są przykładem postaw moralnie jednoznacznych. W celu zapewnienia wyżywienia dzieciom decydują się na zachowania, które oceniane są jako nieetyczne i niemoralne, jak związki z radzieckimi funkcjonariuszami NKWD (np. Pucowa, kobieta sportretowana w Syberiadzie polskiej).

Najdobitniej rolę matek zapewniających dzieciom poczucie bezpieczeństwa w trudnej zesłańczej rzeczywistości, po doświadczeniach utraty domu i ojczystej ziemi, wyraził bohater-narrator powieści Rzeczy nienasycone: „A dopóki jest mama [...] dom można zbudować wszędzie" ${ }^{\text {44 }}$. Dlatego też jednym z najdramatyczniejszych przeżyć, jakich doświadczyli bohaterowie omawianych utworów,

${ }^{42} \mathrm{Z}$. Bitka, Wędrowanie do kresu cierpienia. Motywy archetypowe i symboliczne $w$ prozie Jerzego Krzysztonia, Wydawnictwo Uniwersytetu Opolskiego, Opole 2001, s. 120.

43 J. Krzysztoń, Wielbład na stepie, w: tenże, Wielbłąd na stepie. Krzyż Poludnia, s. 211.

44 A. Czcibor-Piotrowski, Rzeczy nienasycone, Wydawnictwo W.A.B., Warszawa 1999, s. 88. 
była śmierć ich matek na zesłaniu (wyjątkiem jest powieść Krzysztonia, w której matka bohaterów przeżyła pobyt w sowieckiej Rosji). Tak więc utwory są też hołdem złożonym matkom i próbą utrwalenia ich portretów. Zbigniew Domino akcentuje ten fakt, zaznaczając autobiograficzność swojej prozy w dedykacji poprzedzającej opowiadania syberyjskie Cedrowe orzechy: „Pamięci Matki Antoniny z Kaplitów tę książkę poświęcam"45. Również matce zadedykował swoją powieść Rzeczy nienasycone Czcibor-Piotrowski.

Matki bohaterów interpretowanych utworów umierają wskutek chorób, głównie tyfusu. Po śmierci biologicznych matek nad nieletnimi bohaterami powieści opiekę przejmują przybrane matki (Błękitne śniegi), przyszłe macochy (Syberiada polska) czy inne kobiety z bliskiego otoczenia (Rzeczy nienasycone). Natomiast postaci ojców w omawianej prozie są na ogół nieobecne lub odgrywają rolę epizodyczną (Btękitne śniegi). Wyjątek stanowi twórczość Dominy, gdyż w jego narracji o zesłaniu wszyscy członkowie rodziny Dolinów zostali deportowani na Syberię. Po śmierci matki to ojciec przejmuje opiekę nad synami. Jego postać ukazana jest w niezwykle ciepłych barwach, jako opiekuńczego i rozumiejącego swoje dzieci. Niemniej on także, jak wielu Polaków, którzy nie zdołali dotrzeć do Armii Polskiej dowodzonej przez gen. Andersa, decyduje się na wstąpienie w szeregi 1. Dywizji Piechoty im. Tadeusza Kościuszki, opiekę nad dziećmi powierzając ich przyszłej macosze.

W interpretowanych utworach poza motywami rodziny i wyrazistymi portretami matek zwraca uwagę obecność elementów charakterystycznych dla tego szczególnego okresu życia człowieka, jakim jest dzieciństwo, a więc zabawy, przyjaźni z rówieśnikami oraz wątków przygodowych. Obecność elementów przygody w swojej prozie Jerzy Krzysztoń komentuje w następujący sposób: „Gdybym wówczas był człowiekiem dorosłym, zapewne nigdy nie napisałbym podobnej książki, gdyż wątpię, aby mi w ówczesnych okolicznościach patronował duch wielkiej przygody, przygody życia"46. Podobnie interpretuje postawy dzieci w czasie wojny, skupianie się na ich własnym świecie, Andrzej Czcibor-Piotrowski: „Dla większości starszych ludzi wszystko, co się stało od momentu, gdy załomotano kolbami do drzwi, jawi się jako ciąg dantejskich scen. Ja tego tak nie zapamiętałem, pewnie dlatego, że byłem dzieckiem" ${ }^{\text {"47 }}$.

Odmienny sposób przeżywania ówczesnej rzeczywistości wynikał z ograniczonej świadomości dzieci, młodzieży, ale także z faktu znajdowania się pod opieką rodziców, na których spadał główny ciężar troski o zaspokajanie podstawowych

\footnotetext{
${ }^{45}$ Z. Domino, Cedrowe orzechy. Opowiadania syberyjskie, Wydawnictwo Ministerstwa Obrony Narodowej, Warszawa 1974.

${ }^{46}$ Por. J. Krzysztoń, Wielbłą na stepie, Czytelnik, Warszawa 1982. Wypowiedź pisarza umieszczona na skrzydełku obwoluty.

${ }^{47}$ Moje heretyckie spojrzenie, z A. Czciborem-Piotrowskim rozm. G. Leszczyński, „Guliwer” 2001, nr 3, s. 29.
} 
potrzeb życiowych i losy poszczególnych członków rodziny. Różna ocena wydarzeń przez dzieci i dorosłych została ukazana w powieści Wielbłąd na stepie, w scenie, w której zesłańcy zmuszeni zostali do zmiany miejsca pobytu. U dorosłych konieczność opuszczenia w 1941 roku kołchozu Obuchowka, znanego już i oswojonego przez rok pobytu, budzi niepokój, a dla młodych bohaterów, Jurka i Mariuszka „wieść o wyjeździe z kołchozu miała smak radosnej nowiny”"48, gdyż otwierała przed nimi tajemniczą i nieznaną przestrzeń - zauważa snujący opowieść narrator.

Mimo że autorzy prozy wspomnieniowej o wojennym dzieciństwie na zesłaniu zasadniczo podważyli mit dzieciństwa jako Arkadii, niemniej pewne jego elementy, nawet w tych ekstremalnych warunkach, udało się ocalić, co znalazło odzwierciedlenie w literaturze. Dzieciństwo na zesłaniu to bowiem także czas zabawy, kontaktów z rówieśnikami, przyjaźni, miłości, w granicach na jakie pozwalały szczególne, wojenne i zesłańcze okoliczności. Motyw przyjaźni miedzy rówieśnikami, reprezentującymi różne narodowości, przedstawił Jerzy Krzysztoń w utworze Wielbład na stepie. Przyjacielem Jurka, bohatera powieści, stanie się Rosjanin Kolka Samowałow, imponujący chłopcu zaradnością, znajomością stepu, jego roślinności i zwierzyny, umiejący tę praktyczną wiedzę wykorzystać w walce z nękającym dzieci głodem. Dla Jurka rosyjski przyjaciel będzie towarzyszem zabaw, ale także przewodnikiem w nieznanym chłopcu świecie przyrody, w tym przypadku kazachstańskich stepów. Z nim przeżyje różne przygody, weźmie udział w wyprawie po arbuzy, których kradzieży, z narażeniem życia, pod osłoną nocy, dokonają w odległym kołchozie, razem także polują na susły.

Towarzysze zabaw określani jako „ferajna”, reprezentujący różne narodowości, odgrywają ważną rolę w życiu narratora-bohatera Btękitnych śniegów. Dla dzieci owo „spotkanie narodów” wydaje się nie być zdeterminowane stereotypami obciążającymi myślenie o innych nacjach, łączy ich natomiast potrzeba zagospodarowania wolnego czasu, a więc wspólne zabawy. Zdumiewająca jest świadomość wartości wpajanych chłopcom przez rodziców, opór wobec podejmowanych wobec nich prób sowietyzacji w szkole. Jednocześnie trudna sytuacja dzieci zesłańców, więźniów łagrów i lęk, który staje się także ich udziałem, sprawiają, że budzi się w nich instynkt samoobrony, wzmacnia poczucie wspólnoty.

Należy podkreślić, że niezwykle ważnym motywem w interpretowanych powieściach jest proces dorastania i dojrzewania kreowanych postaci. Z tą problematyką w sposób naturalny łączy się temat inicjacji. Terminu 'inicjacja' używam w tym szerokim znaczeniu doświadczenia egzystencjalnego, które w stosunku do jednostki zachodzi po raz pierwszy i jest dla niej konstytutywne,

${ }^{48}$ J. Krzysztoń, Wielbłąd na stepie, w: tenże, Wielbłąd na stepie. Krzyż Poludnia, s. 10. 
wtajemniczenie jest zarazem momentem wejścia w społeczność dorosłych ${ }^{49}$. Do tych najważniejszych sfer życia, które obejmuje inicjacja, należą: miłość, śmierć, sfera praxis i sacrum ${ }^{50}$. Proza pokolenia wojennego najdobitniej akcentuje dwie pierwsze sfery.

W opowieści o losach dzieci na zesłaniu w komunistycznej Rosji przejście z dzieciństwa i wchodzenie w dorosłość dokonuje się w szczególnych okolicznościach, jakie stwarza wojna i sowiecka rzeczywistość. W trudnych warunkach, na które skazani byli przesiedleńcy, usamodzielnienie dokonywało się bardzo szybko. Przymus całodniowej pracy dorosłych wymuszał na dzieciach dużą zaradność, między innymi w opiece nad młodszym rodzeństwem (zaledwie kilkuletnimi braćmi opiekują się bohaterowie powieści Dominy i Krzysztonia) oraz w szukaniu sposobów zaspakajania głodu, nieodłącznie towarzyszącemu egzystencji zesłańców. $Z$ walką o biologiczne przetrwanie wiążą się motywy polowań na różnego rodzaju zwierzęta, które pozwalały zaspokoić głód, bo jak wyznaje bohater Btękitnych śniegów: „Nieustannie byliśmy głodni, obdarci i zawszeni”క1.

Udział w polowaniach dla chłopców, bohaterów prozy zsyłkowej, nosił znamiona przygody, będąc zarazem inicjacją w obszarze praxis. W kazachstańskim stepie były to polowania na susły (Wielbład na stepie), a w syberyjskiej tajdze także na większą zwierzynę, np. na sarny (Syberiada polska, Tajga. Tamtego lata $w$ Kajenie). Rolę przewodników w polowaniach odgrywają lokalni mieszkańcy tych ziem, rówieśnicy lub dorośli, zawodowi myśliwi. Inicjacyjna forma polowań związana była także z bolesnym doświadczeniem zadawania śmierci zwierzętom. Tego typu przeżycia stały się udziałem niezwykle wrażliwego Jurka, bohatera powieści Wielbłąd na stepie.

Wiedza w zakresie różnych dziedzin życia, najczęściej przedwcześnie zdobyta, a także konieczność podejmowania pracy przez starsze dzieci przyspieszały ich proces dorastania. Domino eksponuje ten fakt, charakteryzując bohatera kreowanego w utworze Tajga:

Tymczasem Staszkowi po paru latach syberyjskiej tułaczki chłopięca naiwność wietrzała z głowy jak para z kipiącego czajnika. I tego, co teraz wiedział o Sybirze i tajdze, w książkach by nie wyczytał i w szkole by się nie nauczył. Zresztą o nauce w szkole chłopak nie miał co marzyć. Najważniejsze, żeby z dnia na dzień jakoś przeżyćc ${ }^{52}$.

\footnotetext{
${ }^{49}$ Według Mircei Eliadego jest ona tym typem inicjacji, która obowiązuje wszystkich członków społeczeństwa. Por. tenże, Inicjacja, obrzędy, stowarzyszenia tajemne. Narodziny mistyczne, przeł. K. Kocjan, Znak, Kraków 1997, s. 16-17.

${ }^{50}$ Por. A. Fiut, Przypowieść o wtajemniczeniu, w: tenże, Pytanie o tożsamość, Universitas, Kraków 1995, s. 116-118.

${ }^{51}$ P. Bednarski, dz. cyt., s. 5.

${ }^{52}$ Z. Domino, Tajga. Tamtego lata w Kajenie, Studio Emka, Warszawa 2007, s. 137.
} 
Deportacje to dla dzieci i młodzieży, które je przeżyły, szczególna księga życia, bo, jak pisał Julian Kornhauser, „Samo dzieciństwo jest lekturą. Dziecko czyta świat, a nie książki”"53.

Zesłańcza edukacja obejmowała także inicjację w sferę śmierci. Wśród portretowanych przez pisarzy bohaterów dokonywała się ona na ogół bardzo wcześnie. Nawet kilkuletnie dzieci zaczynały rozumieć, czym jest śmierć. Prozaicy eksponują intensywny sposób przeżywania przez kreowane przez nich postaci doświadczenia śmierci jako zabijania, jako przejawu zła. Śmierć, z którą stykali się bohaterowie, miała różnorodne oblicza i była obecna od początku zesłańczych historii, gdyż pojawiała się już podczas transportu do na ogół bardzo odległych miejsc zesłania w ZSRR. Zetknięcie ze śmiercią z głodu, z powodu chorób i wycieńczenia nie było tak traumatycznym doświadczeniem jak zetknięcie ze śmiercią zadawaną bezpośrednio przez człowieka, w tym przypadku najczęściej funkcjonariuszy NKWD. Szczegółowe opisy takich wydarzeń odnajdujemy w kilku omawianych utworach. Wtajemniczenie w śmierć pierwszoplanowych postaci w opowiadaniu Turczyńskiego Chłopiec na czerwonym koniu, w zbiorze Bednarskiego Błękitne śniegi, a także w powieści Dominy Syberiada polska dokonywało się w podobnych okolicznościach, podczas transportu zesłańców czy przyszłych więźniów łagrów.

Andrzej Turczyński szczegółowo opisuje wstrząs, jaki doznaje siedmioletni bohater opowiadania Chłopiec na czerwonym koniu, będący nie tylko świadkiem zabicia więźniarek przez funkcjonariuszy NKWD, ale także uczestnikiem ich pochówku w zbiorowej mogile, wcześniej zmuszony wraz z innymi dziećmi do przenoszenia zwłok jednej z kilku zastrzelonych. Równie dokładny opis zetknięcia się ze śmiercią zamieścił Domino w Syberiadzie polskiej. Wykreowany w niej bohater, Staś Dolina, jedenastoletni wówczas chłopiec, w czasie wędrówki na Sybir ,pierwszy raz w swoim życiu zobaczył, jak człowiek zabija człowieka" ${ }^{4}$. Zabitym był zagłodzony więzień, który zginął z rąk strażnika łagru dlatego, że zbliżył się do transportu Polaków. Zamieszczony w powieści opis oddaje intensywność przeżyć i doznań bohatera, jego reakcję na to wydarzenie: „Mały Staszek stał obok ojca, trzęsąc się z zimna i strachu. On też to wszystko widział i słyszał"55 - komentuje narrator. Był to jeden z momentów w biografii Staszka Doliny, w czasie którego obecność zła stała się oczywista i przerażająca. Zła, które legło u podstaw stalinowskiego systemu totalitarnego, jego mechanizm jest w powieści stopniowo obnażany.

Te, w sposób szczególny potraktowane przez pisarzy, momenty przeżycia inicjacji kreowanych przez nich bohaterów w związku z bezpośrednim zetknię-

\footnotetext{
53 J. Kornhauser, Samo dzieciństwo jest lektura, „Dekada Literacka” 1996, nr 2, s. 5.

${ }^{54}$ Z. Domino, Syberiada polska..., s. 99.

55 Tamże.
} 
ciem się ze śmiercią były zapowiedzią świata, który był nią przepełniony. Śmierć pozbawiała dzieci najbliższych, czyniąc z nich półsieroty lub sieroty, jak w przypadku bohatera Błękitnych śniegów, kolejno tracącego wszystkich członków rodziny. Na Piotrze ciążyła świadomość, że dziadek Teodor, który jako pierwszy z rodziny poniósł śmierć, został zastrzelony, kiedy pobiegł za wnukiem, gdy ten oddalił się od miejsca postoju pociągu, urzeczony pięknem syberyjskiego krajobrazu - tytułowymi „błękitnymi śniegami” lśniącymi w słońcu. W powieści zwraca uwagę także inny wątek w sposób bardzo szczególny związany ze śmiercią. Jest to postać dziadka Jewtuszenki, starca, którego bohater utworu poznaje w miejscu zesłania. Znajomość z mężczyzną, prowadzone z nim rozmowy na temat śmierci i fakt, że starzec w domu przygotowuje dla siebie trumnę, narrator określa mianem, „świątyni i uniwersytetu”, podkreślając ich znaczenie w kształtowaniu właściwego stosunku do życia i śmierci, co było niezwykle istotne w sytuacji, gdy bardzo młodego bohatera zewsząd osaczała śmierć, a ludzie ulegali degeneracji.

Niejako na przeciwległym biegunie wśród wątków inicjacyjnych sytuuje się wtajemniczenie $\mathrm{w}$ sferę seksualności, w sprawy związane z płciowością człowieka, erotyką. Budzenie się seksualności zwykle jest procesem długotrwałym, przebiegającym powoli, a jego końcowym etapem jest inicjacja erotyczna. Kolejne jej fazy zostały ukazane w prozie Dominy, przedstawiającej wojenne dzieciństwo i młodość dorastającego Staszka Doliny, który w ZSRR przebywał od jedenastego do siedemnastego roku życia. Budzenie się seksualności kreowanego przez Dominę bohatera literackiego dokonuje się etapami, począwszy od pierwszych przyjaźni z rówieśniczkami. Taki charakter ma jego związek z Lubką (Syberiada polska), nadwołżańską Niemką Ritą (Tajga. Tamtego lata w Kajenie), towarzyszą im pierwsze jeszcze dziecinne, nieśmiałe pocałunki, pieszczoty, które stopniowo przeradzają się w fascynację erotyczną. Nieco później dorastający chłopiec zostaje wprowadzony w arkana miłości fizycznej za sprawą młodych kobiet, wojennych wdów (Aniuty, Niurki - Syberiada polska) odczuwających nie tylko pożądanie, ale doświadczających samotności, spragnionych bliskości drugiego człowieka. Domino pokazał budzenie się seksualności jako niezwykle ważny komponent dojrzewania chłopca. Słusznie jednak zarzucano pisarzowi, że nie pogłębił psychologicznie portretu Staszka Doliny.

W mniejszym stopniu wątki związane $\mathrm{z}$ seksualnością są eksponowane w kreacjach bardzo młodych chłopców, bohaterów prozy Bednarskiego i Turczyńskiego. Niemniej w ich literackich biografiach przyjaźnie z dziewczynkami czy pierwsze dziecięce miłości odgrywają ważną rolę. W opowiadaniu Chłopiec na czerwonym koniu uczucie, jakim siedmioletni osierocony bohater darzy najpierw rówieśniczkę Darię, a potem opiekującą się nim czternastoletnią Anastazję, jest wartością ocalającą go. Wywieziony transportem do Arteku, ,raju-dobrych-i-prawdziwych-małych-komunistów”, jak miejsce zesłania określają nadzorcy 
transportu, szuka opieki i wsparcia białoruskiej dziewczynki Anastazji, wykonującej przed wojną w majątku jego rodziców drobne prace, a więc znanej mu, także przez fakt wspólnie odbywanej nauki. Po tragicznej śmierci najpierw zgwałconej, a później z niezwykłym okrucieństwem zamordowanej Anastazji, chłopiec, kierowany nienawiścią, pragnie przetrwać. Dla bohatera utworu ucieczką od wyniszczającej przez głód i pracę łagrowej codzienności są najpierw nocne wizje oniryczne, a później ukradkiem rzeźbiona podobizna Anastazji, będące wyrazem tęsknoty i miłości. Ten ostatni motyw recenzent utworu uznał za realizację mitu o Pigmalionie i Galatei ${ }^{56}$. Rzeźba odegra niezwykle ważną rolę w skonstruowanym w baśniowo-onirycznej konwencji zakończeniu utworu - scenie skoku bohatera w nurt rwącej rzeki z wyrzeźbioną podobizną Anastazji. Jest ono otwarte i symboliczne, obrazuje odzyskanie wolności.

Ze względu na sposób podjęcia tematu dziecięcej erotyki nie można pominąć powieści Czcibora-Piotrowskiego Rzeczy nienasycone, mimo że stała się przedmiotem zainteresowania wielu badaczy ${ }^{57}$. Pisarz skupił się na ukazaniu odkrywania przez dziewięcioletniego chłopca różnych aspektów seksualności. Agnieszka Nęcka, autorka książki Cielesne o(d)stony. Dyskursy erotyczne w polskiej prozie po 1989 roku, zauważa, że ,zaskakujący jest sposób opisu dziejów narratora, traktujący wojnę i zesłanie jedynie jako ramę modalną, na tle której na plan pierwszy wysuwają się problemy związane z cielesnością i poszukiwaniem tożsamości płciowej"s8. Szczególnie intymistyczny charakter prozy Czcibora-Piotrowskiego wyróżnia ją spośród pozostałych tekstów o zesłaniu. Narrator utworu, wcielając się w figurę dziecka, podejmuje temat erotyki bez zahamowań. „Zmetaforyzowany, udziecinniony dyskurs ma - zdaniem Nęckiej - służyć ucieczce przed pornografizowaniem i obscenicznością"59. Utwór ten w dużo większym stopniu niż inne godzi w konwencjonalny, powszechnie przyjęty sposób pisania o seksualności, ale także o II wojnie światowej.

Zróżnicowana proza pisarzy ostatniej generacji pamiętającej wojnę, niezależnie od stopnia artystycznego przetworzenia osobistych doświadczeń z dzieciństwa na zesłaniu, pozostaje świadectwem śladu, jaki wojenny okres życia, charakteryzujący się intensywnością przeżyć, emocji, doznań pozostawił w psychice

\footnotetext{
${ }^{56}$ Por. B. Klukowski, Chłopiec z transportu, „Nowe Książki” 1992, nr 10, s. 41.

${ }^{57}$ Utwór stał się przedmiotem zainteresowania badaczy mitu dzieciństwa w literaturze współczesnej; por. G. Leszczyński, Dzieciństwo utracone. O prozie wspomnieniowej, s. 387-395; A. Szóstak, Między mitem a rzeczywistościa. Topos dzieciństwa w prozie polskiej po roku 1989, Oficyna Wydawnicza Uniwersytetu Zielonogórskiego, Zielona Góra 2012, s. 50-57; E. Rąbkowska, Potrzeba początku: kategoria dzieciństwa w polskiej współczesnej prozie wspomnieniowej (1987-2014), Stowarzyszenie Bibliotekarzy Polskich, Warszawa 2015.

58 A. Nęcka, Perwersja kompensacji. W świecie „,dziecięcej” erotyki Andrzeja Czcibora-Piotrowskiego, w: taż, Cielesne o(d)stony. Dyskursy erotyczne w polskiej prozie po 1989 roku, Wydawnictwo Uniwersytetu Śląskiego, Katowice 2011, s. 83.

${ }^{59}$ Tamże, s 115.
} 
autorów. Dowodem są powroty do przeżyć czasu wojny oraz potrzeba opowiedzenia o nich. Poszukiwania adekwatnych środków ekspresji, które pozwoliłyby na utrwalenie tych szczególnych doświadczeń, zaowocowały przełamywaniem wcześniej stosowanych konwencji pisania o wojnie, na rzecz stylu podbudowanego baśniowością, onirycznością, zabiegami mityzującymi rzeczywistość.

\section{Bibliografia}

Bitka Zbigniew, Wędrowanie do kresu cierpienia. Motywy archetypowe i symboliczne w prozie Jerzego Krzysztonia, Wydawnictwo Uniwersytetu Opolskiego, Opole 2001.

Bednarski Piotr, Błękitne śniegi, Volumen, Warszawa 1996.

Brzuchowska Zofia, Epos nadziei, „Fraza” 2004, nr 3-4, s. 304-307.

Bujnicki Tadeusz, Obrazy ,innego świata” (Losy Polaków w latach 1939-1945 na terytorium ZSRR w emigracyjnej prozie literackiej), „Przegląd Humanistyczny” 1990, nr 4, s. 31-42.

Czaplejewicz Eugeniusz, Polska literatura łagrowa, Wydawnictwo Naukowe PWN, Warszawa 1992.

Czcibor-Piotrowski Andrzej, Rzeczy nienasycone, Wydawnictwo W.A.B., Warszawa 1999.

Czerniawski Adam, Fragmenty niespokojnego dzieciństwa, Aneks, Londyn 1995.

Domino Zbigniew, Cedrowe orzechy. Opowiadania syberyjskie, Wydawnictwo Ministerstwa Obrony Narodowej, Warszawa 1974.

Domino Zbigniew, Syberiada polska, Studio Emka, Warszawa 2001.

Domino Zbigniew, Tajga. Tamtego lata w Kajenie, Studio Emka, Warszawa 2007.

Do zobaczenia w filmie, ze Zbigniewem Dominą rozm. Helena Kowalik, „Przegląd” 2007, nr 27, s. 46-47.

Eliade Mircea, Inicjacja, obrzędy, stowarzyszenia tajemne. Narodziny mistyczne, przeł. Krzysztof Kocjan, Znak, Kraków 1997.

Fiut Aleksander, Przypowieść o wtajemniczeniu, w: tenże, Pytanie o tożsamość, Universitas, Kraków 1995, s. 107-120.

Jagodzińska Maria, Rozwój pamięci w dzieciństwie, Gdańskie Wydawnictwo Psychologiczne, Gdańsk 2003.

Jamrozek-Sowa Anna, Wojna raz jeszcze. Obrazy II wojny światowej w prozie lat dziewięćdziesiątych. w: Literatura polska 1990-2000, red. Tomasz Cieślak, Krystyna Pietrych, Zielona Sowa, Kraków 2002, t. 2, s. 88-110.

Kornhauser Julian, Samo dzieciństwo jest lektura, „Dekada Literacka” 1996, nr 2, s. 5.

Krzysztoń Jerzy, Wielbłąd na stepie. Krzyż Południa, Czytelnik, Warszawa 1987.

Kukułcze gniazda po Syberiadzie, ze Zbigniewem Domino rozm. Helena Kowalik, „Przegląd” 2004, nr 44, s. 37-39.

Leszczyński Grzegorz, Dzieciństwo utracone. O prozie wspomnieniowej, w: tenże, Kulturowy obraz dziecka i dzieciństwa w literaturze drugiej połowy XIX $i$ w XX w. Wybrane problemy, Wydział Polonistyki Uniwersytetu Warszawskiego, Warszawa 2006, s. 374-454.

Leszczyński Grzegorz, Gra w dzieciństwo. Proza wspomnieniowa schytku wieku, w: Pisać poza rok 2000. Studia i szkice literackie, red. Andrzej Lam, Tomasz Wroczyński, Elipsa, Warszawa 2002, s. 227-237.

Moje heretyckie spojrzenie, z Andrzejem Czciborem-Piotrowskim rozm. Grzegorz Leszczyński, „Guliwer” 2001, nr 3, s. 26-30. 
Mrożek Sławomir, Małe listy, Wydawnictwo Literackie, Kraków 1982.

Nawrocki Witold, Sybir poza legenda, „Dziś” 2003, nr 2, s. 121-122.

Nęcka Agnieszka, Perwersja kompensacji. W świecie „dziecięcej” erotyki Andrzeja Czcibora-Piotrowskiego, w: taż, Cielesne o(d)stony. Dyskursy erotyczne w polskiej prozie po 1989 roku, Wydawnictwo Uniwersytetu Śląskiego, Katowice 2011, s. 73-144.

Niewolak Anna, Epos o polskim losie?, „Fraza” 2001, nr 4, s. 265-268

Orski Mieczysław, Chłopiec z gułagu, „Przegląd Powszechny” 1992, nr 11, s. 340-342.

Paliwoda Agata, ,Swoja i obca”. Twórczość literacka Danuty Ireny Bieńkowskiej, Wydawnictwo Uniwersytetu Rzeszowskiego, Rzeszów 2015.

Rabizo-Birek Magdalena, Syberyjski apokryf, czyli apostoł Piotr i jego drużyna, „Twórczość” 1997, nr 7, s. 107-109.

Rąbkowska Ewelina, Potrzeba początku: kategoria dzieciństwa w polskiej współczesnej prozie wspomnieniowej (1987-2014), Stowarzyszenie Bibliotekarzy Polskich, Warszawa 2015.

Rosner Katarzyna, Narracja, tożsamość i czas, Universitas, Kraków 2003.

Sariusz-Skąpska Izabella, Polscy świadkowie GUŁagu. Literatura łagrowa 1939-1989, Universitas, Kraków 2002.

Sylwetki pisarzy stupskich. Andrzej Turczyński. Bio-bibliografia, oprac. Alicja Świetlicka, Stowarzyszenie Bibliotekarzy Polskich, Miejska Biblioteka Publiczna im. Marii Dąbrowskiej, Słupsk 2003.

Szóstak Anna, Między mitem a rzeczywistościq. Topos dzieciństwa w prozie polskiej po roku 1989, Oficyna Wydawnicza Uniwersytetu Zielonogórskiego, Zielona Góra 2012.

Theiss Wiesław, Tułacze dzieci 1940-1945, w: Zniewolone dzieciństwo. Socjalizacja w skrajnych warunkach społeczno-politycznych, Żak, Warszawa 1996, s. 33-114.

Turczyński Andrzej, Chłopiec na czerwonym koniu, w: Turczyński Andrzej, Tryptyk ruski, Orthdruk, Białystok 1998, s. 87-195.

Tyborczyk Jan, Andrzej Turczyński. „,Tryptyk ruski”, „Akant” 1999, nr 11, s. 25-27.

Współcześni polscy pisarze i badacze literatury. Słownik biobibliograficzny, red. Jadwiga Czachowska, Alicja Szałagan, Wydawnictwa Szkolne i Pedagogiczne, t. 2, Warszawa 1994.

Anna Wal

\section{Literary settlements with childhood in exile in the Soviet Union Introductory considerations}

\section{(Summary)}

The article discusses autobiographical prose of the writers of the war generation, devoted to the problems of deportation into the interior of the Soviet Union during World War II. The considerations include the works published in Poland after 1989: Andrzej Turczyński’s Chłopiec na czerwonym koniu (1991), Piotr Bednarski’s Błękitne śniegi (1996), Andrzej Czcibor-Piotrowski's Rzeczy nienasycone (1999), Zbigniew Domino's Syberiada polska (2001) and Tajga. Tamtego lata $w$ Kajenie (2007). The carried out analysis of the literary texts provides the grounds for justification of the thesis that the writers broke with the earlier existing conventions of war writing, referring to the close to the child's imagination poetics of fairy-tale, parable, dream, mythologisation of 
reality, and that while showing exiled childhood in the Soviet Union they used very specific topoi (the image of parents, mainly of the mother, the motif of friendship and peer groups, as well as of adventure and initiation).

Keywords: literature of exile, childhood in the Soviet Union; autobiographical prose; the writers of the war generation 